\title{
BAYESIAN REGRESI SURVIVAL PADA PROSES KEJADIAN HIVIAIDS DI JAWA TIMUR
}

\author{
Nur Mahmudah1)* \\ Sukono2) \\ 1)Jurusan Statistika, Fakultas Teknologi dan Sains, Universitas Nahdlatul Ulama Sunan Giri \\ JI. Jendral Ahmad Yani No. 10 Jambean Bojonegoro 62115, Indonesia \\ 2)Jurusan matematika, Fakultas Matematika dan IImu Pengetahuan Alam, \\ Universitas Padjadjaran, Sumedang, Indonesia \\ e-mail: mudah15@gmail.com*
}

\begin{abstract}
Survival analysis is a statistical procedure that describes a mathematical model that is often applied in various studies, especially in health. One application of survival analysis is to determine the rate of survival and the factors affecting HIV / AIDS sufferers in East Java. HIV / AIDS is a virus that attacks or infects white blood cells, causing a decrease in immune cells. This disease causes a decrease in productivity in the health and economic sectors of a country. Even if the disease continues to increase, the weak economic development will decrease due to the treatment of HIVIAIDS and the risk of death of people infected with the HIV / AIDS virus is getting higher in East Java. In addition to these health and economic quality factors, factors such as residents' knowledge of the disease. By knowing the factors of HIVIAIDS survival rate, mathematical modelling can be done to estimate the duration of the patient's survival power comprehensively and accurately. In this study, we want to find out what factors affect the survival rate of HIV/AIDS using the 3-Parameter Lognormal Survival Link Function model in which the method of parameter estimation used is the Bayesian MCMC-Gibbs Sampling method. The best models is the 3-parameter lognormal survival with frailty that is normally distributed and factors affect the survival rate of HIVIAIDS is education $\left(X_{3}\right)$, marital status $\left(X_{5}\right)$, Stadium of the patient $\left(X_{8}\right)$, adherence of therapy $\left(X_{10}\right)$, opportunistic infection $\left(X_{11}\right)$ and risk factor of infection $\left(X_{13}\right)$.
\end{abstract}

Keywords: Bayesian, Gibbs-Sampling, HIVIAIDS, MCMC-Gibbs Sampling

\begin{abstract}
ABSTRAK
Analisis survival merupakan suatu prosedur statistika yang menjelaskan model matematis yang seringkali diaplikasikan dalam berbagai penelitian, terutama di bidang kesehatan. Salah satu penerapan dari analisis survival adalah untuk mengetahui laju bertahan hidup dan faktor-faktor yang mempengaruhi penderita HIVIAIDS di Jawa Timur. Penyakit HIVIAIDS adalah virus yang menyerang atau menginfeksi sel darah putih yang menyebabkan turunnya sel kekebalan tubuh. Penyakit ini mengakibatkan penurunan produktivitas di bidang kesehatan dan ekonomi di suatu negara. Bahkan apabila penyakit ini terus meningkat maka lemahnya perkembangan ekonomi akan menjadi menurun akibat pengobatan penyakit HIVIAIDS dan resiko kematian dari orang yang terinfeksi virus HIVIAIDS tersebut semakin tinggi di Jawa Timur. Disamping faktor kualitas kesehatan dan ekonomi tersebut, faktor seperti pengetahuan warga terhadap penyakit HIVIAIDS. Dengan mengetahui faktor-faktor laju bertahan hidup penyakit HIVIAIDS dapat dilakukan pemodelan
\end{abstract}


matematis untuk memperkirakan durasi daya survival secara aktual, dan komprehensif. Tujuan artikel dalam penelitian ini adalah menjelaskan faktor-faktor yang mempengaruhi laju bertahan hidup pasien terhadap penyakit HIVIAIDS dengan menggunakan model Survival Lognormal 3 parameter Link Function. Metode estimasi parameter yang digunakan adalah metode Bayesian MCMC-Gibbs Sampling. Model Survival Lognormal 3 Parameter dengan Frailty yang berdistribusi normal menghasilkan faktor-faktor yang mempengaruhi laju bertahan hidup pasien HIVIAIDS di Jawa Timur adalah pendidikan $\left(X_{3}\right)$, status perkawinan $\left(X_{5}\right)$, stadium penderita $\left(X_{8}\right)$, kepatuhan terapi $\left(X_{10}\right)$, infeksi oportunitis $\left(X_{11}\right)$ dan resiko penularan $\left(\mathrm{X}_{13}\right)$.

Kata kunci: Bayesian, Gibbs-Sampling, HIVIAIDS, MCMC-Gibbs Sampling 
Human Immunodeficiency Virus (HIV) adalah penyakit sejenis virus yang menyerang atau menginfeksi sel darah putih yang menyebabkan turunnya sel kekebalan tubuh (Ersha dan Ahmad, 2018).Sampai saat ini, penyakit HIVIAIDS menduduki peringkat kedua di Jawa Timur. Dari 38 Kota/Kabupaten yang berada di Provinsi Jawa Timur, Kota Surabaya menduduki peringkat pertama pada tahun 2016 (Mahmudah, et.al., 2018). Rumah sakit yang menyediakan rekam medis yang baik terkait skrining penderita HIVIAIDS dengan terapi ART(anti retroviral) dan karakteristik penderita adalah Rumah Sakit Umum Soetomo. Terapi ARTmempunyai peran besar dalam meningkatkan kualitas hidup penderita HIVIAIDS, menurunkan angka kematian dan kesakitan, serta meningkatkan harapan hidup masyarakat (Arum, et.al., 2019). Angka kematian penyakit HIVIAIDS terus meningkat sehingga menimbulkan biaya yang tinggi untuk melakukan perawatan, penangganan, dan penyembuhan penyakit HIVIAIDS (Kebede, et.al., 2020). Penelitian terkait dengan penyakit HIVIAIDS yang tepat digunakan adalah analisis survival karena untuk menentukan faktor-faktor yang mempengaruhi terjadinya suatu hal atau peristiwa dengan faktor risiko kejadian terhadap waktu (Munfaridah dan Indriani, 2016). Analisis survival telah banyak diaplikasikan dalam berbagai bidang kesehatan atau medis dan dikenal dengan berbagai istilah dibidang lain seperti event history analysis (Prabawati, et.al., 2018).

Berdasarkan penelitian yang dilakukan oleh (Wuryandari, et.al., 2020) penerapan model survival pada kejadian HIVIAIDS di Provinsi Jawa Timur, yaitu memodelkan waktu hingga penderita dinyatakan meninggal, atau rujuk ke luar dari ART yang menggunakan distribusi Weibull dengan efek spasial. Penelitian juga dilakukan oleh (Munfaridah dan Indriani, 2016) yang menggunakan analisis survival dengan pendekatan Bayesian yang berdistribusi Weibull 3 parameter pada kasus DBD di Kota Malang. Penderita DBD di Kota Malang memiliki laju kesembuhan yang sama. Pada kenyataannya distribusi data survival dapat direpresentasikan sebagai satu distribusi dengan jelas sehingga penelitaan ini mengkaji distribusi yang ada pada data survival yaitu distribusi Lognormal 3 parameter. Distribusi ini diharapkan memberikan solusi kepada penderita HIVIAIDS yang kejadiannya dipengaruhi oleh beberapa faktor yaitu tingkat pendidikan, jumlah populasi berisiko (pekerja seks komersial, pelanggan prostitusi dan orang yang mempunyai seksual aktif) dan jumlah VCT (Voluntery Counselling dan Testing) sehingga penyebaran HIVIAIDS di Jawa Timur signifikan.

Pada akhirnya, penelitian ini menghasilkan model komputasi regresi survival yang dapat dijadikan sebagai langkah penanganan secara optimal pada penderita HIVIAIDS dan bahan pertimbangan melakukan sosialisasi tentang penanganan penyakit HIVIAIDS sehingga dapat mengurangi penderita HIVIAIDS di Provinsi Jawa Timur.

\section{TINJAUAN PUSTAKA}

\section{Model Regresi Survival Lognormal 3 Parameter}

Survival berasal dari kata survive yakni ketahanan atau kelangsungan hidup individu.

Analisis survival adalah analisis statistika untuk menganalisis data yang berasal dari variabel respon waktu (time) sampai terjadinya suatu kejadian (event) (Prabawati, et.al., 2018). Model regresi survival digunakan untuk menjelaskan bagaimana risiko (hazard) terjadinya suatu event tertentu pada suatu waktu dipengaruhi oleh berdasarkan teori yang menerangkan kejadian (Wuryandari, et.al., 2020).

Model Cox merupakan model semi parametrik karena tidak memerlukan informasi tentang distribusi yang mendasari waktu survival dan fungsi baseline hazard tidak harus ditentukan untuk mengestimasi parameter (Tampubolon dan Noeryanti, 2018). Fungsi hazard digunakan untuk menaksir peluang objek mengalami event pada waktu ke-t (Suhartini, et.al., 2018). Dalam analisis 
survival, model regresi Cox lebih tepat digunakan daripada model regresi logistik karena model logistik mengabaikan waktu survival dan informasi tentang penyensoran (Dewi, et.al., 2020).

Distribusi waktu perawatan penderita HIVIAIDS. Pada Penelitian ini mengikuti distribusi Lognormal 3 parameter. Berikut adalah lama waktu perawatan HIVIAIDS dengan fungsi kepekatan peluang distribusi Lognormal 3 parameter (Solomon, et.al., 2018):

$$
f(t ; \beta, \tau, \gamma)=\frac{1}{(t-\gamma) \tau \sqrt{2 \pi}} \exp \left\{-\frac{[\ln (t-\gamma)-\beta]^{2}}{2 \tau^{2}}\right\}
$$

di mana $\tau, \beta, \gamma=$ parameter Lognormal 3 parameter, $t>\gamma \geq 0,-\infty<\beta<\infty, \tau>0$ dan $\gamma$ adalah parameter lokasi. Jika t adalah variabel respon (lama perawatan penderita HIVIAIDS) yang memiliki distribusi Lognormal 3 Parameter, maka $y=\ln (\mathrm{t}-\gamma)$ memiliki distribusi normal dengan rata-rata $\mu$ dan ragam $\tau^{2}$. Ketika $\gamma=0$, maka distribusi berubah menjadi 2 Parameter Lognormal (Mahmudah, et.al., 2018). Distribusi ini akan dimasukan pada model regresi survival dengan model sebagai berikut:

$$
\begin{aligned}
h(t) & =h_{0}(t) \mu \\
& =\frac{1}{\tau(t-\gamma)} \exp \left(\beta_{0}+\beta_{1} X_{1}+\beta_{2} X_{2}+\ldots+\beta_{p} X_{p}\right) \\
& =\frac{1}{\tau(t-\gamma)} \exp \left(\beta_{0}\right) \exp \left(\beta_{1} X_{1}+\beta_{2} X_{2}+\ldots+\beta_{p} X_{p}\right) \\
& =\left\{\frac{1}{\tau(t-\gamma)} \exp \left(\beta_{0}\right)\right\} \exp \left(\beta_{1} X_{1}+\beta_{2} X_{2}+\ldots+\beta_{p} X_{p}\right)
\end{aligned}
$$

dimana:

$t \sim \operatorname{Lognormal}(\tau, \beta, \gamma)$

$\mu=\exp \left(\boldsymbol{\beta}^{\mathbf{T}} \mathbf{x}_{i j}\right)+\varepsilon_{i}, \quad \varepsilon_{i} \mid \varepsilon_{-i}, \boldsymbol{\beta} \sim \operatorname{Normal}(s, r)$

$\tau, \beta, \gamma=$ parameter lognormal 3 parameter

$s, r \quad=$ parameter distribusi normal

$\varepsilon_{i}=$ Frailty

$\beta_{0}, \beta_{1}, \ldots, \beta_{p} / \boldsymbol{\beta}=$ parameter model survival

$X_{1}, X_{2}, \ldots, X_{p}=$ variabel yang diamati

$h_{0}(t)=$ parameter baseline hazard

$h(t)=$ model regresi survival 
Model Survival terdapat sumber-sumber variansi atau keragaman yang tidak dapat dijelaskan melalui vektor kovariat dalam model mengakibatkan terjadinya bias dan inkonsistensi pada pendugaan parameter survival. Salah satu cara untuk mengatasi bias dan inkonsistensi pada parameter model survival adalah dengan menyertakan frailty dalam model. Frailty model bisa diasumsikan menggunakaan distribusi normal atau tidak memiliki distribusi (Mahmudah, et.al., 2018).

Pengujian parameter bertujuan untuk mengetahui pengaruh variabel prediktor terhadap variabel respon (Dewi, et.al., 2020). Pengujian parameter yang digunakan pada pendekatan Bayesian adalah dengan pengujian credibel Interval yang memiliki nilai batas bawah sebesar 2,5\% dan batas atas sebesar 97,5\% (Mahmudah, et.al., 2018). Kriteria keputusannya akan tolak $H_{0}$ jika credibel interval tidak memuat nilai 0 dengan kesimpulan bahwa variabel prediktor berpengaruh secara signifikan terhadap variabel respon. Berikut adalah hipotesis yang digunakan (Mahmudah, et.al., 2018):

$H_{0}=\beta_{j}=0$ (variabel prediktor ke-j tidak berpengaruh terhadap variabel respon)

$H_{1}=\beta_{j} \neq 0$ (variabel prediktor ke-j berpengaruh terhadap variabel respon)

Penggunaan beberapa metode untuk mencari model yang sesuai pada kasus model survival, dapat dipilih model yang paling tepat dengan melihat nilai kriteria kebaikan model (Goodness of fit) yaitu dengan mencari nilai dugaan untuk data. Metode yang dapat digunakan adalah Deviance Information Criterion (DIC) parameter (Solomon, et.al., 2018). Metode Bayesian MCMC, fungsi likelihood telah bergabung dengan sebaran prior menjadi sebaran posterior (Mahmudah, et.al., 2018). Model dengan nilai DIC yang terkecil, dipilih sebagai model terbaik. Kriteria kebaikan model ini untuk menghitung ukuran keakuratan model dalam model Bayesian. Statistik DIC pada Bayesian MCMC sebagai berikut:

$$
D I C=\ddot{D}_{\text {avg }}(y)+p_{D}=2 \ddot{D}_{\text {avg }}(y)-\mathrm{D}_{\hat{\theta}}(y)
$$

dimana:

$$
\begin{array}{ll}
\mathrm{D} & =\text { deviasi dari sebaran posterior } \theta \\
\ddot{D}_{\text {avg }}(y) & =\text { rata-rata nilai } \mathrm{D} \text { dari sebaran posterior } \theta \\
D_{\widehat{\theta}}(y) & =\text { nilai } \mathrm{D} \text { yang diduga pada rata-rata posterior } \\
p_{D} & =\ddot{D}_{\text {avg }}(y)-D_{\widehat{\theta}}(y) \\
\text { avg } & =\text { rata-rata }
\end{array}
$$

\section{Bayesian MCMC-Gibbs Sampling}

Pemodelan pada Bayesian didasarkan pada model posterior yaitu memadukan data masa lalu sebagai informasi prior dan data pengamatan yang digunakan sebagai penyusun fungsi likelihood (Destiarina, et.al., 2019). Estimator pada pendekatan Bayesian adalah mean atau modus dari distribusi posterior-nya. Jika suatu parameter $\theta$ dianggap sebagai variabel yang diamati, maka informasi mengenai sebelum melakukan observasi disebut distribusi prior (Candrawengi, et.al., 2020). Setelah observasi, maka sejumlah observasi akan mempunyai likelihood yang dinamakan likelihood data (Jamaludin dan Septiawan, 2021). Pemodelan Bayesian pada persamaan distribusi posterior adalah sebagai berikut (Destiarina, et.al., 2019): 


$$
f(\theta \mid x)=\frac{f(x \mid \theta) f(\theta)}{f(x)} \propto f(x \mid \theta) f(\theta)
$$

dengan:

$$
\begin{array}{ll}
f(\theta \mid x) & =\text { posterior } \\
f(x \mid \theta) & =\text { fungsi likelihood } \\
f(\theta) & =\text { distribusi prior } \\
x & =\text { data } \\
\theta & =\text { parameter }
\end{array}
$$

Markov Chain Monte Carlo (MCMC) merupakan pendekatan numerik dalam mendapatkan distribusi posterior (Erango, 2020). Metode Bayesian yang sangat rumit dapat diselesaikan dengan metode simulasi MCMC yang menghasilkan data sampel berdasarkan skenario sampling tertentu (Jamaludin dan Septiawan, 2021). Distribusi posterior yang dihasilkan tidak sederhana, sehingga estimasi terhadap parameter dilakukan menggunakan Gibb Sampling (Katianda, et.al., 2021).

Markov Chain merupakan proses stokastik $\left\{\boldsymbol{\theta}^{(1)}, \boldsymbol{\theta}^{(2)}, \ldots, \boldsymbol{\theta}^{(K)}\right\}$ sehingga dapat dinyatakan dalam persamaan berikut ini:

$$
f\left(\theta^{(K+1)} \mid \theta^{(K)}, \ldots, \theta^{(1)}\right)=f\left(\theta^{(K+1)} \mid \theta^{(K)}\right)
$$

Dalam membangkitkan sampel dari $p(\theta \mid x)$, lebih dahulu harus disusun rantai Markov Chain dengan syarat yaitu $f\left(\theta^{(\mathrm{K}+1)} \mid \theta^{(\mathrm{K})}\right)$ harus mudah dibangkitkan dan distribusi stasioner dari Markov Chain merupakan distribusi posterior $p(\theta \mid x)$, dengan langkah seperti berikut:

1. Menentukan nilai awal $\boldsymbol{\theta}^{(0)}$.

2. Membangkitkan sampel dengan iterasi sebanyak K.

3. Mengamati konvergenitas data sampel.

4. Menggunakan $\left\{\boldsymbol{\theta}^{(B+1)}, \boldsymbol{\theta}^{(B+2)}, \ldots ., \boldsymbol{\theta}^{(K)}\right\}$ sebagai sampel untuk analisis posterior.

5. Membuat plot distribusi posterior dan membuat ringkasan dari distribusi posterior seperti mean, median, dan selang kepercayaan (Banner, et.al., 2020).

Estimasi parameter model regresi survival Lognormal 3 parameter dengan algoritma Gibbs Sampling dapat dijelaskan sebagai berikut:

1. Menentukan nilai awal untuk masing-masing parameter pada distribusi Lognormal 3 parameter.

2. Memperoleh urutan acak dari masing-masing distribusi.

3. Mengulangi langkah kedua sampai dinyatakan konvergen (Banner, et.al., 2020).

\section{METODE}

Penelitian ini menggunakan data sekunder rekam medis rawat jalan mengenai karakteristik keadaan perawatan penderita penyakit HIVIAIDS di Rumah Sakit Soetomo Surabaya. Data yang diambil adalah data perawatan penderita penyakit HIVIAIDS dengan tes CD4 dan skrining lengkap. Dari data perawatan tersebut dikategorisasikan menjadi 2, yakni data tersensor dan data tidak tersensor. Data dikatakan tersensor jika penderita dinyatakan meninggal, berhenti dan merupakan kunjungan terakhir (lost follow up). Data dikatakan tidak tersensor jika penderita sembuh atau keluar 
dari ART. Waktu pengambilan data rekam medis mulai tanggal 27 Desember 2017 sampai 26 Januari 2018. Variabel respon dalam penelitian ini adalah waktu perawatan atau ketahanan hidup (Y). Variabel prediktor yang dikaji adalah jenis kelamin $\left(X_{1}\right)$, usia $\left(X_{2}\right)$, pendidikan $\left(X_{3}\right)$, status pekerjaan $\left(X_{4}\right)$, status perkawinan $\left(X_{5}\right)$, berat badan $\left(X_{6}\right)$, kadar $C D 4$ absolut $\left(X_{7}\right)$, stadium penderita $\left(X_{8}\right)$, status fungsional $\left(X_{9}\right)$, kepatuhan terapi $\left(X_{10}\right)$, infeksi oportunitis $\left(X_{11}\right)$, status TB (Tubercolosis) $\left(X_{12}\right)$, faktor risiko penularan $\left(X_{13}\right)$, riwayat $A R V\left(X_{14}\right)$, adherence $A R V$ (kepatuhan minum obat $)\left(X_{15}\right)$, rejimen $\mathrm{ARV}\left(\mathrm{X}_{16}\right)$ dan $\mathrm{PMO}$ atau pendamping minum obat $\left(\mathrm{X}_{17}\right)$. Berikut adalah langkah-langkah dalam menyelesaikan analisis regresi survival dengan pendekatan Bayesian yang memiliki distribusi Lognormal 3 parameter:

1. Melakukan analisis deskriptif

2. Mengumpulkan data mengenai penderita perawatan penderita penyakit HIVIAIDS di Rumah Sakit Soetomo.

3. Mengidentifikasi peristiwa, adanya data tersensor dan tidak tersensor yang dinyatakan sebagai berikut:

a. $\delta=0$ yang merupakan data tersensor, misalnya jika penderita tidak mengalami kegagalan failure event dalam kasus ini mengikuti terapi ART hingga penderita dinyatakan meninggal, berhenti dan lost follow up/kunjungan terakhir.

b. $\delta=1$ yang merupakan data tidak tersensor, misalnya jika penderita perawatan penyakit HIVIAIDS mengalami failure event atau dinyatakan rujuk keluar dari ART atau kondisi membaik.

4. Menambahkan "add-ins" distribusi Lognormal 3 parameter dalam WinBUGS sebagai generator parameter untuk distribusi Lognormal 3 parameter. Langkah-langkah sebagai berikut:

a. Install WinBUGS 1.4.

b. Install Blackbox Component Builder.

c. Menyiapkan file yang berisi koneksi pengabungan distribusi baru ke WinBUGS.

d. Menyiapkan template UnivariateTemplate.odc untuk penambahan distribusi baru.

e. Menyiapkan input yang diperlukan dalam UnivariateTemplate.odc untuk penambahan distribusi Lognormal 3 parameter, yang terdiri dari pdf distribusi Lognormal 3 parameter dan fungsi Log-likelihood dari distribusi Lognormal 3 parameter dan CDF dari distribusi Lognormal 3 parameter.

f. Membuat coding program berdasarkan input pada langkah ke (e) dan menempatkannya dalam prosedur yang bersesuaian.

g. Melakukan komplikasi program.

h. Melakukan validasi program.

5. Menentukan model survival dengan distribusi lognormal 3 Parameter menggunakan paket program open source WinBUGS. Berikut Menentukan model dan parameter survival dengan distribusi lognormal 3 parameter menggunakan simulasi Markov Chain Monte Carlo (MCMC) dan Gibb Sampling denganlangkah menentukan model dan parameter survival dengan distribusi yang dapat dijelaskan sebagai berikut:

$>$ Menentukan fungsi Likelihood

$>$ Menentukan distribusi prior parameter model survival Lognormal 3 parameter berdasarkan informasi dari data.

$>$ Penentukan inisialisasi parameter $\tau, \beta, \gamma$ menggunakan 1-Step MCMC 
6. Menentukan mean dan keragaman dari model survival pada distribusi lognormal 3 parameter dengan mengestimasi parameter model survival $\tau, \beta, \gamma$ melalui simulasi MCMC dengan Gibbs sampling seperti dalam langkah sebagai berikut:

$>$ Menentukan fungsi likelihood

$>$ Menentukan distribusi prior masing-masing parameter berdasarkan informasi dari data.

$>$ Menentukan nilai awal untuk masing-masing parameter model menggunakan 2-steps MCMC.

7. Membangkitkan $T$ sampel $\theta^{1}, \theta^{2}, \ldots \ldots \theta^{T}$ dari distribusi posterior $p(\theta \mid x)$ dilakukan update $T$ sebanyak yang dibutuhkan $n$ kali agar proses Marcov Chain terpenuhi.

8. Algoritma konvergen dijelaskan sebagai keadaan ketika algoritma telah mencapai stasioner pada distribusi posterior Lognormal 3 parameter.

9. Mendapatkan summaries dari distribusi posterior (mean, median dan selang kepercayaan 95\%) pada distribusi Lognormal 3 parameter.

10. Pemilihan model terbaik dengan nilai DIC.

11. Membentuk dan menginterpretasikan model survival yang berdistribusi Lognormal 3 parameter.

\section{HASIL DAN PEMBAHASAN}

Penyusunan model regresi survival untuk mengetahui variabel prediktor mana yang berpengaruh terhadap waktu survival hingga penderita dinyatakan rujuk keluar dengan ART atau meninggal, pindah dan lost follow up. Langkah pertama dilakukan analisis deskriptif untuk mengetahui karakteristik penderita perawatan HIVIAIDS di RS Soetomo Surabaya. Jumlah penderita HIVIAIDS di RS Soetomo Surabaya sebanyak 440 pasien dengan karakteristik jenis kelamin perempuan sebanyak $162(36,8 \%)$ pasien dan laki-laki sebanyak $278(63,2 \%)$ pasien. Hal ini dapat disimpulkan bahwa penyebaran penyakit HIVIAIDS di Jawa Timur terbesar berjenis kelamin laki-laki karena memiliki jumlah penderita HIVIAIDS terbanyak. Karakteristik lainnya dapat diketahui berdasarkan waktu perawatan atau ketahanan hidup, usia, berat badan, dan persentase CD4 absolut.

Tabel 1. Analisis Deskriptif Variabel Penderita HIVIAIDS

\begin{tabular}{lrrrrr}
\hline \multicolumn{1}{c}{ Variabel } & $N$ & Minimum & Maximum & Mean & Std. Deviation \\
\hline Usia & 440 & 13,00 & 60,00 & 34,577 & 9,3452 \\
Berat badan & 440 & 18,00 & 104,00 & 54,615 & 11,8717 \\
CD4 absolut & 440 & 1,00 & 1220,00 & 184,12 & 179,711 \\
Lama perawatan & 440 & 11,00 & 2775,00 & 1015,25 & 681,746 \\
\hline
\end{tabular}

Berdasarkan Tabel 1 dapat diketahui bahwa dari 440 penderita HIVIAIDS, sebagian besar lama perawatan penderita HIVIAIDS di RS Soetomo Surabaya adalah sekitar 1.015 hari (2,8 tahun). Jika dilihat dari lama perawatan penderita HIVIAIDS hingga dalam keadaan rujuk keluar dari ART atau membaik, paling sebentar penderita perawatan 11 hari dan paling lama penderita perawatan 2.775 hari atau hampir 8 tahunan. Berikut ini merupakan karakteristik penderita HIVIAIDS berdasarkan status penderita dan status ketersensoran. 
Tabel 2. Status Penderita HIVIAIDS Berdasarkan Jenis Kelamin $\left(X_{1}\right)$

\begin{tabular}{llccc}
\hline \multirow{2}{*}{ Lama Perawatan } & Status & \multicolumn{2}{c}{ Jenis Kelamin } & \multirow{2}{*}{ Total } \\
\cline { 3 - 4 } & Ketersensoran & Perempuan & Laki-Laki & \\
\hline Meninggal, pindah, lost follow up & Tersensor & $26(16 \%)$ & $61(21,9 \%)$ & $87(19,8 \%)$ \\
Rujuk keluar dengan ART & Tidak tersensor & $136(84 \%)$ & $217(78,1 \%)$ & $353(80,2 \%)$ \\
\hline Total & & $162(100 \%)$ & $278(100 \%)$ & $440(100 \%)$ \\
\hline
\end{tabular}

Tabel 2 menunjukkan bahwa persentase laki-laki yang rujuk keluar dengan ART lebih besar dibandingkan dengan perempuan. Persentase laki-laki yang meninggal, pindah, dan lost follow up lebih besar dibandingkan dengan perempuan. Dengan demikian dapat disimpulkan bahwa kebanyakan penderita HIVIAIDS berjenis kelamin laki-laki.

Efek random (frailty) pada model survival merupakan error yang tidak teramati ke dalam fungsi hazard sehingga mampu mewakili heterogenitas data fungsi hazard. Frailty yang berdistribusi normal mampu mengatasi kebiasan pada model yang ada efek heterogenitas seperti model survival (Mahmudah, et.al., 2018). Dalam mengetahui apakah model survival dengan frailty normal merupakan model survival terbaik pada distribusi Lognormal 3 parameter maka model tersebut kemudian dibandingkan dengan survival tanpa frailty.

Tabel 3. DIC Pada Model Survival

\begin{tabular}{lc}
\hline \multirow{2}{*}{ Model } & DIC \\
\cline { 2 - 2 } & Lognormal 3 Parameter \\
\hline Survival tanpa frailty & 7785,770 \\
Survival dengan normal frailty & 7784,090 \\
\hline
\end{tabular}

Berdasarkan Tabel 3 dengan menggunakan kriteria kebaikan model DIC, model survival lognormal 3 parameter dengan frailty yang berdistribusi normal menunjukan nilai DIC terkecil dibandingkan dengan model tanpa frailty. Dengan demikian dapat dikatakan bahwa model dengan frailty berdistribusi normal mampu memodelkan HIVIAIDS di Jawa Timur lebih baik dibandingkan dengan model survival tanpa frailty. Artinya bahwa terdapat heterogenitas yang tidak bisa dijelaskan atau tidak terwakili oleh faktor-faktor dalam model survival tanpa frailty. Berikut hasil estimasi parameter model survival yang disajikan pada Tabel 4 .

Tabel 4. Estimasi Parameter Model Regresi Survival Lognormal 3 Parameter dengan Frailty Normal

\begin{tabular}{ccccc}
\hline Parameter & Mean & $2,50 \%$ & Median & $97,50 \%$ \\
\hline$\beta_{1}$. & 0,0065 & $-0,0095$ & 0,00647 & 0,0231 \\
$\beta_{2}$ & $-0,0023$ & $-0,0213$ & $-0,0019$ & 0,0155 \\
$\beta_{3}$ & 0,0020 & $-0,0124$ & $-0,00217$ & $-0,0180$ \\
$\beta_{4}$ & 1,8901 & $-0,0163$ & 4,5801 & 0,0172 \\
$\beta_{5}$ & $-0,0015$ & $-0,0170$ & $-0,0017$ & $-0,0148$ \\
$\beta_{6}$ & $-0,0016$ & $-0,0178$ & $-0,0016$ & 0,0159 \\
\hline
\end{tabular}




\begin{tabular}{ccccc}
\hline Parameter & Mean & \multicolumn{1}{c}{$2,50 \%$} & \multicolumn{1}{c}{ Median } & $97,50 \%$ \\
\hline$\beta_{7}$ & 0,0058 & $-0,0109$ & 0,0059 & 0,0225 \\
$\beta_{8}$ & 0,0215 & 0,0049 & 0,02172 & 0,0371 \\
$\beta_{9}$ & $-0,0027$ & $-0,0205$ & $-0,00261$ & 0,0154 \\
$\beta_{10}$ & $-0,0127$ & $-0,0291$ & $-0,0127$ & $-0,0054$ \\
$\beta_{11}$ & $-0,0117$ & $-0,0289$ & $-0,0116$ & $-0,0053$ \\
$\beta_{12}$ & 5,8401 & $-0,0165$ & 2,2701 & 0,0194 \\
$\beta_{13}$ & 0,0017 & $-0,0131$ & $-8,6101$ & $-0,0178$ \\
$\beta_{14}$ & 0,0027 & $-0,0137$ & 0,00241 & 0,0189 \\
$\beta_{15}$ & 7,5401 & $-0,0189$ & 8,4201 & 0,0205 \\
$\beta_{16}$ & 0,0087 & $-0,0119$ & 0,00956 & 0,0258 \\
$\beta_{17}$ & 0,0033 & $-0,0113$ & 0,00359 & 0,0175 \\
$\beta_{0}$ & 0,0212 & 0,0711 & 2,4201 & 0,3205 \\
$\tau$ & 1,888 & 1,865 & 1,888 & 0,1048 \\
$\gamma$ & 1,634 & 1,311 & 1,627 & 1,997 \\
\hline
\end{tabular}

Berdasarkan Tabel 4 adalah faktor-faktor yang dianggap signifikan mempengaruhi laju bertahan hidup penderita HIVIAIDS jika nilai pada selang 2,5\% hingga 97,5\% tidak memuat nilai 0 . Tabel 4 menunjukkan tidak semua faktor berpengaruh signifikan terhadap laju bertahan hidup penderita HIVIAIDS. Faktor yang mempengaruhi laju kesembuhan adalah: Pendidikan (X3); Status perkawinan (X5); Stadium penderita (X8); Kepatuhan terapi (X10); Infeksi oportunitis (X11); dan faktor risiko penularan (X13). Pada Tabel 4 kolom 2 (nilai mean) merupakan besaran parameter model sedangkan ketiga kolom berikutnya adalah besarnya nilai estimasi pada selang kepercayaan 97,5\%. Parameter $\tau$ merupakan kostanta dalam fungsi hazard pada model survival. Parameter $T$ sebesar 1,888 signifikan karena selang 2,5\% hingga 97,5\% tidak memuat nilai 0 . Kostanta tersebut mempengaruhi laju bertahan penderita HIVIAIDS dari kematian yang artinya terdapat dependensi frailty yang tidak terjelaskan dalam model regresi survival. Dependensi frailty terjadi antar unit pengamatan dalam satu kelompok sedangkan frailty antar kelompok akan saling independen.

Tabel 4 merupakan estimasi parameter model regresi survival dengan distribusi Lognormal 3 parameter dengan frailty berdistribusi normal. Nilai koefisien 0,0065 pada variabel Jenis Kelamin (X1) menandakan bahwa penderita perempuan yang mengikuti program ART mempengaruhi laju bertahan penderita HIVIAIDS dari kematian sebesar $\exp (0,0065)$ kali dibandingkan penderita lakilaki. Hal ini menunjukkan bahwa penderita perempuan cenderung cepat untuk sembuh atau laju kesembuhan perempuan exp $(0,0065)$ kali lebih cepat daripada laki-laki. Hal ini dapat disimpulkan bahwa secara keseluruhan kematian penderita HIVIAIDS lebih banyak laki-laki daripada perempuan dikarenakan laki-laki memiliki ketahanan fisik (tubuh) yang lebih rentan terhadap virus HIVIAIDS didukung dengan deskriptif data pada Tabel 5. Deskriptif data menunjukkan jumlah pasien HIVIAIDS terbanyak berjenis kelamin laki-laki dengan rentang usia 21-30 tahun. Hal ini dapat dijelaskan bahwa secara keseluruhan jumlah penderita HIVIAIDS lebih banyak berusia usia 21-30 tahun. Interpretasi sama untuk semua variabel. Berikut adalah karakteristik responden berdasarkan deskriptif variabel jenis kelamin dan usia. 
Tabel 5. Karakteristik Data Pasien Penderita HIVIAIDS

\begin{tabular}{ccc}
\hline Usia Responden (thn) & Perempuan & Laki-laki \\
\hline$<20$ & 3 & 12 \\
$21-30$ & 57 & 103 \\
$31-40$ & 57 & 97 \\
$41-50$ & 34 & 48 \\
$>51$ & 11 & 18 \\
\hline Jumlah & 162 & 278 \\
\hline
\end{tabular}

Berdasarkan Tabel 4 menyediakan rangkuman posterior (posterior summaries) parameter model regresi survival dengan frailty normal maka hazard penderita HIV/AIDS dengan faktor-faktor yang mempengaruhinya dapat dimodelkan sebagai berikut:

$$
\begin{aligned}
h(t, X) & =h_{0}(t) \exp \left(\beta_{0}+\beta_{1} X_{1}+\beta_{2} X_{2}+\beta_{3} X_{3}+\ldots+\beta_{p} X_{p}\right) \\
& =\frac{1}{\tau(t-\gamma)} \exp \left(0,0212+0,0065 X_{1}-0,0023 X_{2}+0,0020 X_{3}+1,8901 X_{4}-0,0015 X_{5}-0,0016 X_{6}+0,0058 X_{7}+\ldots+0,0087 X_{17}\right) \\
& =\frac{1}{1,888(t-1,634)} \exp \left(0,0212+0,0065 X_{1}-0,0023 X_{2}+0,0020 X_{3}+1,8901 X_{4}-0,0015 X_{5}-0,0016 X_{6}+0,0058 X_{7}+\ldots+0,0087 X_{17}\right)
\end{aligned}
$$

Berdasarkan hasil model regresi survival lognormal 3 parameter dengan frailty normal maka dapat ditentukan hazard penderita HIVIAIDS berdasarkan waktu (hari) dan faktor-faktor yang mempengaruhi nilai hazard. Misalnya hazard penderita HIVIAIDS pada variabel riwayat ARV $\left(\mathrm{X}_{14}\right)$ bahwa penderita pernah mendapatkan ARV sebelum mengikuti program ARV. Nilai hazard ini diperoleh dengan menganggap bahwa faktor lain adalah konstan dan hazard penderita hanya dipengaruhi oleh kenyataan bahwa penderita pernah mendapatkan ARV sebelum mengikuti program

\section{SIMPULAN}

Berdasarkan hasil analisis dapat disimpulkan bahwa faktor-faktor yang signifkan berpengaruh terhadap laju bertahan hidup penderita HIVIAIDS meliputi: Pendidikan $\left(X_{3}\right)$; Status perkawinan $\left(X_{5}\right)$; Stadium penderita $\left(X_{8}\right)$; Kepatuhan terapi $\left(X_{10}\right)$; Infeksi oportunistis $\left(X_{11}\right)$; Faktor resiko penularan $\left(X_{13}\right)$ dan parameter $\mathrm{T}$. Parameter t merupakan dependensi frailty yang tidak terjelaskan dalam model regresi survival log normal 3 parameter. Model regresi survival Lognormal 3 parameter dengan frailty normal menggunakan metode komputasi MCMC-Gibbs Sampling dapat dijadikan sebagai alternatif pemodelan survival. Dengan demikian pemodelan model regresi survival ini dapat digunakan untuk menjelaskan model survival yang lebih kompleks dan memprediksi waktu bertahan hidup atau survival time bagi penderita HIVIAIDS. 


\section{REFERENSI}

Arum, M. J. N., Kartiningrum, E. D., \& Fardiansyah, A. (2019). Analisis Survival Penderita Hiv/Aids Di Rsud Prof. Dr. Soekandar Kabupaten Mojokerto. Hospital Majapahit. (Jurnal Ilmiah Kesehatan Politeknik Kesehatan Majapahit Mojokerto), 11(1), 47-59.

Banner, K. M., Irvine, K. M., \& Rodhouse, T. J. (2020). The use of Bayesian priors in Ecology: The good, the bad and the not great. Methods in Ecology and Evolution, 11(8), 882-889.

Candrawengi, N. L. P. I., Iriawan, N., \& Irhamah, I. (2020). Pemodelan Survival pada Kejadian Demam Berdarah Dengue di Surabaya Timur dengan Pendekatan Bayesian. Jurnal Sains dan Seni ITS, 9(1), D8-D14.

Destiarina, U., Hadijati, M., Komalasari, D., \& Fitriyani, N. (2019). Estimasi Parameter Distribusi Mixture Eksponensial dan Weibull dengan Metode Bayesian Markov Chain Monte Carlo. Eigen Mathematics Journal, 1(1), 28-38.

Dewi, A. Y., Dwidayati, N. K., \& Agoestanto, A. (2020). Analisis Survival Model Regresi Cox Dengan Metode Mle Untuk Penderita Diabetes Mellitus. Unnes Journal Of Mathematics, 9(1), 31-40.

Erango, M. A. (2020). Bayesian Joint Modeling of Longitudinal and Survival Time Measurement of Hypertension Patients. Risk management and healthcare policy, 13, 73.

Ersha, R. F., \& Ahmad, A. (2018). Human Immunodeficiency Virus-Acquired Immunodeficiency Syndrome dengan Sarkoma Kaposi. Jurnal Kesehatan Andalas, 7, 131-134.

Jamaludin, P. P., \& Septiawan, D. (2021). Peran Motivasi Dalam Upaya Meningkatkan Disiplin Kerja Karyawan (Studi Pada Waroeng Ss Spesial Sambal Cabang Bsd Tangsel). Jurnal Semarak, 1(1), 140-147.

Katianda, K. R., Goejantoro, R., \& Satriya, A. M. A. (2021). Estimasi Parameter Model Regresi Linier dengan Pendekatan Bayes. Jurnal Eksponensial, 11(2), 127-132.

Kebede, A., Tessema, F., Bekele, G., Kura, Z., \& Merga, H. (2020). Epidemiology of survival pattern and its predictors among HIV positive patients on highly active antiretroviral therapy in Southern Ethiopia public health facilities: A retrospective cohort study. AIDS Research and Therapy, 17(1), 1-8.

Mahmudah, N., Iriawan, N., \& Purnami, S. W. (2018). Bayesian Spatial Survival Models for HIVIAIDS Event Processes in East Java. Indian Journal of Public Health Research \& Development, 9(11).

Munfaridah, M., \& Indriani, D. (2016). Analisis Kecenderungan Survival Penderita HIV (+) dengan Terapi ARV Menggunakan Aplikasi Life Table. Jurnal Biometrika dan Kependudukan, 5(2), 99-106.

Prabawati, S., Nasution, Y. N., \& Wahyuningsih, S. (2018). Analisis Survival Data Kejadian Bersama dengan Pendekatan Efron Partial Likelihood. Jurnal Eksponensial, 9(1), 75-84.

Solomon, B. J., Kim, D. W., Wu, Y. L., Nakagawa, K., Mekhail, T., Felip, E., \& Mok, T. S. (2018). Final overall survival analysis from a study comparing first-line crizotinib versus chemotherapy in ALK-mutation-positive non-small-cell lung cancer. J Clin Oncol, 36(22), 2251-2258. 
Suhartini, A., Rahmawati, R., \& Suparti, S. (2018). Analisis Kurva Survival Kaplan Meier Menggunakan Uji Log Rank (Studi Kasus: Pasien Penyakit Jantung Koroner Di Rsud Undata Palu). Jurnal Gaussian, 7(1), 33-42.

Tampubolon, R. R., \& Noeryanti, N. (2018). Model Regresi Cox Pada Data Kejadian Berulang Identik Untuk Analisis Penyakit Tuberkulosis Terhadap Pasien Laki-Laki. Jurnal Statistika Industri Dan Komputasi, 3(02), 33-41.

Wuryandari, T., Kartiko, S. H., \& Danardono, D. (2020). Analisis Survival Untuk Durasi Proses Kelahiran Menggunakan Model Regresi Hazard Additif. Jurnal Gaussian, 9(4), 402-410. 